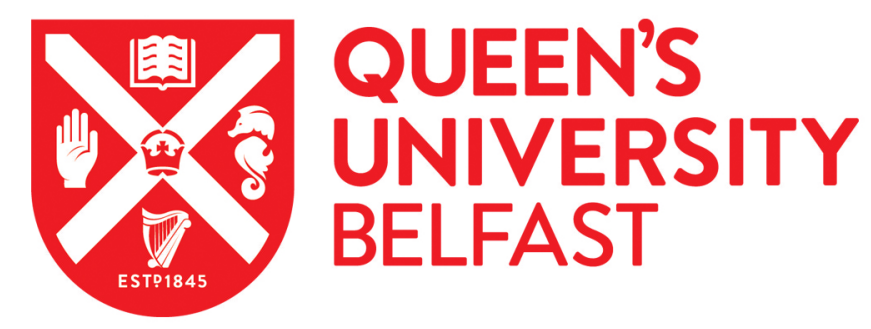

\title{
"We Decided the Museum Would Be the Best Place for Them": Veterans, Families and Mementos of the First World War
}

Foster, A-M. (2019). "We Decided the Museum Would Be the Best Place for Them": Veterans, Families and Mementos of the First World War. History \& Memory, 31(1), 87-117.

\author{
Published in: \\ History \& Memory
}

Document Version:

Publisher's PDF, also known as Version of record

Queen's University Belfast - Research Portal:

Link to publication record in Queen's University Belfast Research Portal

Publisher rights

(c) 2019 Indiana University Press.

This work is made available online in accordance with the publisher's policies. Please refer to any applicable terms of use of the publisher.

\section{General rights}

Copyright for the publications made accessible via the Queen's University Belfast Research Portal is retained by the author(s) and / or other copyright owners and it is a condition of accessing these publications that users recognise and abide by the legal requirements associated with these rights.

Take down policy

The Research Portal is Queen's institutional repository that provides access to Queen's research output. Every effort has been made to ensure that content in the Research Portal does not infringe any person's rights, or applicable UK laws. If you discover content in the Research Portal that you believe breaches copyright or violates any law, please contact openaccess@qub.ac.uk. 


\section{PROJECT MUSE}

"We Decided the Museum Would Be the Best Place for Them": Veterans, Families and Mementos of the First World War

Ann-Marie Foster

History \& Memory, Volume 31, Number 1, Spring/Summer 2019, pp. 87-117 (Article)

Published by Indiana University Press

$\Rightarrow$ For additional information about this article https://muse.jhu.edu/article/719781 


\title{
"We Decided the Museum Would Be the Best Place for Them"
}

\section{Veterans, Families and Mementos of the First World War}

\author{
Ann-Marie Foster
}

Although it is generally considered that there was relatively little interest in the First World War throughout the 1970s and 1980s in Britain, these decades constitute a key moment in time when the embodied memories of the war transitioned into the cultural memory we are familiar with today. This article examines the transmission of memories of the First World War from veterans and their families to museums. It uses the Durham Light Infantry Museum, a small regimental museum in the northeast of England, as a case study to examine who donated war-related objects and their reasons for doing so.

Keywords: First World War; family transmission; war museums; generations; personal memory; institutional memory; material culture

Scholarly discussions surrounding popular reception of the First World War in Britain in the 1970s and 1980s tend to dwell on only two developments: the publication of Paul Fussell's The Great War and Modern Memory in 1975 and the creation of the Western Front Association in 1980. ${ }^{1}$ There is otherwise a paucity of work concerning these decades: they are framed by the widespread interest of the general public in the conflict in the 1960s and 1990s and therefore appear almost barren in comparison. Historians point to the 1960s as a high point of popular engagement with the war, reflected in the BBC television series The Great War (1964), the play and subsequently film Ob! What a Lovely War (1963 and 1969 respectively), Alan Clark's blistering attack on British command- 
ers in The Donkeys (1961), and a proliferation of memoirs published by veterans of the conflict. ${ }^{2}$ Similarly, the British public's renewed interest in the war is seen at the end of the 1980s and the beginning of the 1990s, with Blackadder Goes Forth (1989), the fourth and final series of the BBC sitcom Blackadder, and the Regeneration series of novels by Pat Barker (1991-95), which provided the cultural touchstone for perceptions of the war that have lasted to the present day. ${ }^{3}$ Yet, despite the perceived lack of interest in the First World War in the 1970s and 1980s, these decades were vital to the transmission of memory of the war between individuals, families and institutional archives.

This article examines this complex transmission of memory through the donation of First World War objects to the Durham Light Infantry (DLI) Museum, a small regimental museum in the northeast of England, between 1970 and 1990. The museum closed its doors to the public in 2016 and the DLI Collection is now available for public view upon request at its new location in Spennymoor, County Durham. The DLI Museum was opened in 1969 under the auspices of the Libraries and Museums Committee of Durham County Council. It was chosen for this study as it is broadly representative of a council-run regimental museum for the period under consideration. This was a typical arrangement by the end of the 1980s: a 1990 report concerning museums of the armed services by the Museums and Galleries Commission found that of the sixty-two regimental museums in Britain forty-two were maintained by local authorities. ${ }^{4}$ Between 1970 and 1990 the DLI Museum accessioned just over 3,000 objects of which 648 were identified as clearly related to the First World War. ${ }^{5}$ It is the information contained within the institutional archive that allows for an exploration of the meaning of the donation of First World War-related objects in the 1970s and 1980s. Handwritten letters, sent by donors to accompany their objects, were preserved for just over two hundred First World War-related items accessioned over the period. The letters explained the donors' reasons for gifting their possession and provided a select object biography for the curators to use when evaluating whether the museum was interested in acquiring the item. While the importance of objects and their meanings to donors have been explored by other scholars in different contexts, the letters and bureaucratic forms associated with the objects have often been overlooked as mere administrative paperwork. However, they constitute a hidden archive of memories and attitudes toward the 
donated objects and of relationships between veterans, their families and the museum. ${ }^{6}$ These letters, filed away in a bureaucratic archive (of which the DLI Museum is merely one, indicating the potential richness of this source base), offer an insight into remembrance of the First World War in the twentieth century in a way that has previously been neglected.

As Dan Todman has emphasized, the 1970s and 1980s saw the passing of the majority of veterans. Upon their death many personal collections of objects relating to the war, photographs, even medals, and in some cases bronze plaques dedicated to the fallen, were thrown away. With their dwindling numbers, veterans lost the ability to influence the popular culture, which now remembered them in absentia. As a result the cultural memory of the First World War began to be increasingly presented as a homogenized and stable narrative. ${ }^{8}$

It was at this junction, between fading living memory and solidifying cultural memory, that the transmission of memory was enacted by veterans and their families. Jan Assmann has written that cultural memory develops through stages of memory types; from communicative to generational, before these memories are codified within cultural memory. ${ }^{9}$ Honing this concept further, Aleida Assmann has commented on the moment when an embodied intergenerational memory transforms into a disembodied transgenerational one which forms the basis of cultural memory. ${ }^{10}$ These points in memory transformation are where the donors are situated. Veterans who shared their life stories (the embodied communicative memory actors) and their children (the carriers of generational memory) were teetering on the edge of cultural memory. The death of the veterans and the decision of the next generation to deposit family items in an institutional repository can be seen as marking a subtle shift from communicative (embodied) memory to institutional (disembodied) memory of the First World War.

Within this wider shift toward a cultural memory of the war are three types of memory transmission: personal to communicative (veterans and their peers to their families); personal to institutional (the same generation to the museum); and communicative to institutional (second- and third-generation family memory to museum). These memory transmissions occurred between members of different generations, the museum as a cultural institution of memory and the museum as experienced through human interaction with curators. 
MEMORY AND MUSEUMS

The space in which museums and memory intersect is highly complex. Museums are seen as one of the three cultural institutions of memory, but the memories being offered in the process of donation are often personal (or communicative) ones. ${ }^{11}$ Theoretical discussions of the transmission of personal memory have been pioneered by Aleida Assmann, who argues that although personal memory is lost upon the death of the owner, anecdotes from one's past can be transmitted in the form of communicative memory and can last within a social group for between eighty to a hundred years. ${ }^{12}$ The process of donation melds personal and social memory with cultural memory, thus complicating this standard personal-to-social trajectory. These memory transactions between individual and museum exist at the juncture between Jan Assmann's model of communicative and cultural memory, in the space where the everyday memory of the communicative transforms into the "figures of memory" of the cultural. ${ }^{13}$

Museums have been described as being in a "status of latency" and are viewed as repositories of a set cultural history which are only active within society when called upon to be so. ${ }^{14}$ Therefore the process of donating an item (and the memories associated with it) to a museum suggests that the donor is attempting to graft his or her personal memory (or indeed a familial memory of the soldier in question) onto a fixed cultural memory instead of its being mediated through the communicative memory of the family which would occur if the object were kept in the family home. Museums and memory holders therefore have a symbiotic relationship: museums need memories in order to function as an effective public repository of the past as much as donors need museums to store their memories effectively. A museum, at its simplest, had been described as "a place that stores memories." 15 As Gaynor Kavanagh has explained, museums "need memories as a primary source" to produce experiences that elicit remembrance in a visitor or they fail to function. ${ }^{16}$

Museums that depict war have a more difficult task in accessing and presenting socially acceptable narratives of past events. As Sue Malvern has written, war museums occupy a strange space within civil society. As they are often seen as "monuments to cultural achievement," a museum dedicated to war can be interpreted as an institution that "celebrates the uncelebratable." 17 Finding a way of expressing the horrors of war in a way 
that nonetheless engages with public audiences can be fraught, and interpretation of conflict has to be sensitively handled. This tension, and the difficulties presented by the interpretation of past conflict, is particularly evident in regimental museums, which, as Simon Jones has noted, are more complex than a traditional war museum as they were created "for the specific purpose of instilling and fostering in the regiment the esprit de corps which enables it to fight more effectively." 18 The concept of a regimental esprit de corps was challenged in the 1960s when many regimental collections were amalgamated with local ones after army reforms made many of the older regiments obsolete. ${ }^{19}$ The folding of regimental museums into local ones took place, somewhat ironically, during a period when public heritage sites were rapidly developing and this created a small crisis in the regimental museum sector, as many such museums sought to establish their identity within a changing military landscape while appealing to an increased public interest in heritage..$^{20}$ After the amalgamation of many regiments in the British army in the 1960s and early 1970s, regimental museums ran the risk of becoming museums of local military history as opposed to active repositories of a particular regiment.

Barton C. Hacker and Margaret Vining commented on this shift in function of local regimental museums in relation to their display policies in the 1980s. Regimental museums began to shy away from artefact-heavy, non-narrative presentations, turning instead into dialogical spaces which used the stories of individuals as a way of making the regiment relevant to new visitors. ${ }^{21}$ As Ross Wilson has argued, this shift toward the individual soldier became popular after the Second World War and was reinforced in the 1960s and 1970s by veterans recording oral histories of the First World War. ${ }^{22}$ The DLI Museum began recording oral histories of First World War veterans on behalf of the Imperial War Museum (IWM) in the late 1980s. ${ }^{23}$ Veterans who contacted the DLI Museum were asked if they wanted to record their memories and those who did were interviewed by Peter Hart, then North East representative of the IWM Sound Archives, or his assistant Harry Moses. As in the case of donation, these interviewees were self-selecting. Before they approached the DLI Museum they may have known that these recordings were taking place, but there was seemingly no official or sustained campaign to recruit DLI veterans to record their reminiscences. 
Those involved with the running of the DLI Museum were evidently cognizant of these public perceptions of regimental museums during the period. In the foreword to the catalogue for a special exhibition of the treasures of the regiment in 1978, Colonel Watson, chairman of the Society of Friends of the Regimental Museum, wrote that some people "consider military museums nothing more than repositories for ancient muskets and dusty uniforms." ${ }^{24}$ With this choice of words Watson alluded to the museum as an embodiment of the regiment while signaling his awareness of those who perceived military history as drums, drills and dragoons. By staging exhibitions of regimental treasures, an attempt was made to attract a broader public beyond those individuals involved in the regiment, such as those with an interest in art, silverware or general militaria.

Despite this effort by the museum to appeal to a wider audience, the curator of the DLI Museum at the time remembers there being a noticeable lack of public interest in the DLI and recalls having to dispose of regimental histories throughout the 1970s and 1980s because they could not be sold to this uninterested public. ${ }^{25}$ Similarly, Matthew Richardson has found that while veterans were attempting to engage with the public via the publication of their memoirs in these years, the popularity of Armistice Day was steadily decreasing. ${ }^{26}$ These trends were reflected in the Western Front Association, created in 1980, whose membership included very few veterans and was mainly composed of people who had a family connection or scholarly interest in the First World War. The Association's membership increased from 282 in 1980 to 3,500 a decade later, which indicated moderate interest among the general public. ${ }^{27}$

As much as the regiment may have sought to change perceptions of military history, it was also influenced by the prevailing cultural memory of the First World War as a Western Front-centric conflict of "lions led by donkeys" and "blood, mud and futility." ${ }^{28}$ Indeed, the DLI Museum itself contributed to perpetuating these perceptions of the war during the period. A 1970s exhibition catalogue describes the war as "a miserable, static and frequently bloody conflict. The front line trench was a soldier's only environment for long periods at a time." 29 This rhetoric echoes a pathos-laden narrative of war that began to be popularized in the 1960s, notably by Clark's The Donkeys, and was continued in the 1970s by literary critics such as Paul Fussell in his The Great War and Modern Memory. ${ }^{30}$ Within this highly constructed narrative of war, laden with poignant 
descriptions of loss of life and horrific living conditions, the DLI Museum located the crucible in which the regiment had been formed. The curatorial staff disseminated literature about the regiment which claimed that the First World War had "cemented the ties that bind Regiment and County together" through the high loss of life of local men (the majority of DLI soldiers were indeed local). ${ }^{31}$

\section{THE DLI DONORS: SOME GENERAL TRENDS}

It was among this reinvention of the military museum, from introspective to outward-facing institution, that the donation of First World War artefacts to the DLI Museum took place. As a local regimental collection it is perhaps unsurprising that the majority of donors to the museum lived in County Durham. The county the donor lived in at the time of donation is known for 522 objects. Of these 48 percent of the donors lived in County Durham, with another 14 percent living in the adjacent county of Tyne and Wear. The remainder of the donors were scattered around various counties, with the highest concentration outside of County Durham and Tyne and Wear living in neighboring North Yorkshire. Yorkshire as a whole provided 7 percent of donations, with 4 percent originating from North Yorkshire alone. Northumberland only provided 3 percent of donors. This is curious as, during the First World War, Fenham Barracks in Newcastle (the recruitment office for the DLI) was situated next to the recruitment office for the Northumberland Fusiliers. If one office had a longer queue outside, potential recruits simply joined the back of the other..$^{32}$ One donor wrote about the disappointment of men traveling to Newcastle to find that the regiment they wanted to join was over-subscribed, saying that "they [potential recruits] were so keen to get into uniform that they were referred to the H.Q. of the Durham Light Infantry." ${ }^{33}$ The only international donations were from Canada (totaling 1 percent of overall donations).

From the DLI Museum accession records it is apparent that certain types of objects were consistently donated: paper items (including maps, photographs and diaries), medals, weapons, pieces of uniform, and memorials (such as a Next of Kin Memorial Plaque or a Commonwealth War Graves Commission photograph of a soldier's wooden gravemarker). 
Margaret Higgonet has previously noted that the majority of war souvenirs collected by returning soldiers were stolen German relics. ${ }^{34}$ Interestingly, this trend was not reflected in the numbers of German relics donated to the museum, which only amounted to 3 percent of the items donated: possibly these items were not as popular as assumed, were of interest to the family so were kept, or were perhaps disposed of or sold, rather than donated. Overall, popular items were often small, easily portable, and generally contained identifying information on them such as the soldier's name or regimental number.

The majority of items donated during the period were paper-based: maps, diaries and photographs, which amounted to 32 percent of the accessioned items. Medals, with the soldier's name and regimental number engraved upon the rim, were the second largest group at 28 percent. Often collections of personal effects were donated together, and small collections such as papers, medals and memorial items (often death pennies and personal effects returned from the front) made up 20 percent of the donations. Other items were not as popular; memorials accounted for 3 percent, and weapons and uniforms were 3 and 5 percent respectively. The remaining donations were of miscellaneous material, as varied as biscuits, pincushions and a hairbrush. ${ }^{35}$ The only items that were not accepted by the museum were weapons as they were not legally allowed to take firearms into the collection. ${ }^{36}$

It is the letters accompanying these donations that provide insights into the donors' motivations. Through correspondence with the curators the donors left a rich archive of attitudes toward museums, donation and perceptions of the First World War. These dialogues between the museum and the individual donors were often complex and could take place over the course of several weeks (if not months or, occasionally, years). Standard paperwork, in which donors signed away their objects to the collection, was necessary for every item entering the museum, and donors were sent a standard letter of thanks from the museum. The donors' letters varied from basic object biographies to lengthy correspondence reminiscing upon the history of the donor or the original owner of the item. Although these letters were private, they were constructed by the donors to appeal to the curators of the museum. The way these letters were formulated suggests that donors were aware that their items were going to a regimental museum to be viewed by a gatekeeper who controlled access to the collection, and 
some listed their military experience as a way of gaining legitimacy, while others adopted a deferential approach.

The letters reveal that the majority of donors were somewhat uncertain about museological practices and did not necessarily have knowledge of accession procedures - that some objects were displayed while others were stored in museum archives - and what type of items the museum accepted. Some donors, however, sought to ensure that the recipient would know that the sender was an fait with the workings of the institution by utilizing phrases such as "I realise you will have comprehensive records covering this period but I am happy to offer them to you if they may be useful for archival purposes," but these were a rare minority. ${ }^{37}$ Some donors did not fully understand the connection between regimental museums and locality. One woman visited the Derby Art Gallery with a box of DLI medals as it was the closest museum to where she lived, assuming that they would find a home there, not realizing that they were likely to be redirected to the DLI Museum. ${ }^{38}$ In 1981 a woman offered her father's medals alongside a clipping of an obituary in his union journal, published in 1962, asking the DLI museum to "please destroy [the clipping] as I am sure you won't be interested in what ex-soldiers did after the war," seemingly unaware that it would be of archival interest. ${ }^{39}$ Others did not realize that donation to the museum did not automatically mean that their items would be on display, and successive curators often had to write to concerned family members reassuring them that their relative's objects were still valued. In response to letters asking for items to be returned if they were not valued by the DLI Museum, the curators tried to placate the upset families by explaining that the items had been donated to the DLI Museum "as a gift for the collections" and therefore could not be removed without the Board of Trustees' consent (which was somewhat difficult to obtain).$^{40}$

Significantly, a number of people donated to the museum without understanding how it functioned but with the implicit feeling that the institution was the right one for their object to reside in. The grandson of a veteran donated his medals, drawing upon conceptions of soldierly camaraderie, writing "in a way I feel that they properly belong with their fellows." ${ }^{41}$ This was sometimes couched in the language of an item going "home" or of a "duty" for the object to reside in its county museum. This sentiment is reflected in the language used in the letters from the donors that lived outside of County Durham in which the donors indicated that 
they felt drawn to the museum because of its regional character. ${ }^{42}$ In Dominick Dendooven's study of items donated to the In Flanders Field Museum in the late 1990s, he cites the fact that the museum is located in Ypres as a key motivation for the donors to return items to their original locale. ${ }^{43}$ This sense of the local combined with a limited understanding of museum practice is perhaps why these items were sent to the DLI Museum instead of the Imperial War Museum in London. Those residing in County Durham may not have felt the pull of London and the IWM but instead favored a repository located within the county for which the soldier had fought.

\section{MEMORIES AND THE MUSEUM}

Interactions between the donors and the DLI Museum reveal a pressing concern about the passage of time and the prolonged safety of the objects. The letters show an emerging awareness of the first-generation donors' own mortality. Frank discussions about a lack of family to bequeath objects to and therefore the need to donate to a museum developed during the correspondence. The curators played an active role in these conversations and often engaged elderly donors in a proto-form of reminiscence work. The generation to which the donor belonged is known for 198 of the accessioned objects during the period: 53 percent of the objects were donated by members of the first generation (veterans, who accounted for 28 percent of the donations, and their contemporaries), 42 percent by the second generation (their children's generation) and 5 percent by the third generation. ${ }^{44}$ Many donors attempted to interest the curators in the objects they wanted to donate by using persuasive language and highlighting the interest of the item. One widow, describing a piece of reasonably standard trench art, among other war relics she had in her possession, wrote that she had "one item ... which is unique you could [sic] find any other like it ... \& there are other unique items too. ${ }^{~} 45$

Veterans in particular seemed to recognize that the most effective way to ensure that one's item was retained by the museum was to have been in both the regiment and the conflict relating to the object one was donating. As much as the museum needed their memories, the veterans also had a vested interest in keeping the hub of their former regiment 
open through the donation of new material. Some letters suggesting a special relationship with the museum based on military service also occurs in second-generation donor letters. One second-generation donor felt the need to return his father's medals to the DLI Museum, commenting "as a Green Howard [another British regiment] I appreciate the importance of the Regimental Museum in the life of the Regiment." ${ }^{36}$ Another emphasized his previous experience of donating to a military museum, explaining "I having myself served in the RAF from 1927 to 1950, have given many photos from my collection to the RAF Museum, Hendon, and I hope that you accept these [photographs] for yours." ${ }^{47}$ This reference to military service was perceived by the donors as a type of validation. While they had not necessarily fought in the First World War (although they might have experienced the conflict), this strategic mention of military service was clearly regarded as a means of achieving legitimacy of a kind that could not be gained by those who did not have a military background.

Letters from veterans suggest that their motivations for donation were, in part, linked to their advancing age. In 1973 a veteran wrote "now I live with my memories. I was 80 years old on the 14 th of last month. I live alone in my own house on the Pension of a grateful(?) [sic] country, but a Home Help comes for three hours each week to clean up and dust for me." Another simply wrote "I am just the wrong side of eighty years \& want to try and settle up." ${ }^{48}$ One veteran donated a set of wire breakers, reflecting that he was "delighted that it had finally got a good home, before being lost when I left it behind, as I am now 79 years old." ${ }^{49}$ These men independently decided that the DLI Museum was the correct place for their items and, implicitly, the memories associated with them. A veteran decided to donate his medals, and, writing to the museum on his behalf, his daughter noted that they "always meant something to him and [so] we decided the museum would be the best place for them." ${ }^{50}$

Donation may be understood not just as a way of consolidating a memory within popular culture before one's passing but as part of a psychological urge to transfer autobiographical memory to a different repository (normally family but in this case an institution) which occurs in later life. ${ }^{51}$ Those veterans donating their personal memory to the museum via these letters were attempting to deposit their memories in an institution that offered a sense of permanence instead of entrusting them to the ephemeral world of generationally based family memory. Donat- 
ing an object with a life story attached created a lieu de mémoire of the individual which cemented the donor's memory within a fixed space. This appearance of immutability reassured donors that their memory would not be in danger of becoming lost as it might if the object (and thereby the person's story) was kept in the family, or indeed, if there was no family to continue their memory. ${ }^{52}$

This is a particularly clear motivation in all the first-generation donors who had no descendants to assume custodianship of the object. One woman who donated her brother's medals, explained “you see I am getting old, and there is no-one else who would want them." ${ }^{53}$ In these cases the donors' overriding priority was to preserve some type of personal memory (of the conflict or of a loved one involved in the war) after they had passed away. In her study of the everyday objects of mourning in Australia, Margaret Gibson quotes a woman who commented "You can pass on an object ... but can you really pass on the feeling that you have for that object?" ${ }^{44}$ In this respect, the letters constitute a safeguard against the loss of personal memory. By supplying object biographies, donors evidently hoped to tempt the curators into accepting the object and thereby ensure that the object's story would still be associated with it when it entered the museum space. Thus, one man, too young to have fought but old enough to have memories of the war, donated his brother's Next of Kin Memorial Plaque, stating:

I have taken care of the plaque since my parents [sic] death some years ago \& have looked well after it ... my problem is that my wife \& I have no children to follow us in caring for it our younger relatives do not wish to take over the care of it.... Please forgive me for taking up your time, but if you have a good home for the plaque I would really appreciate it. ${ }^{55}$

Another woman wrote to the museum on behalf of her father, and explained that "now that he is nearly 82 years of age he says he would very much like the museum to have them [medals] rather than they should be lost or unappreciated after he has departed this life. ${ }^{\prime 56}$ As these were items of significance to the donor, family members wanted to impress upon the museum the importance of the object to increase the likelihood of its being accepted into the collection. 
In explaining their reasons for donation, and the significance of the item to them as individuals, the donors attempted to build a relationship with the curator which would grant their family items a place in the collection. Some donors attempted to secure their item's place in the museum by outlining their military experience as a way of proving that they were familiar with the museum's remit. One donor commented in a letter accompanying her late husband's medals that "I also served in the lst World War I was the first girl to leave Sacriston to nurse the wounded. You will understand what Nov 11 means to me." ${ }^{17}$ Here the emotions surrounding a national day of remembrance were invoked to impress upon the curators the solemnity with which she regarded the First World War.

The longest chains of correspondence were between elderly single or widowed veterans and the museum. At times these donors encouraged the curators to contact other veterans in similar circumstances as a type of institutional support network. ${ }^{58}$ The responses by the museum offered veterans and other first-generation donors a chance to further reminisce by describing other personal aspects of their past. At times these could be quite personal memory triggers. John Rumsby, an assistant curator during the first part of the period in question, informed a veteran that a diary he had donated some years before had now been transcribed and sent him a copy, in response to which the donor not only expressed his gratitude, but also provided further information, writing that the marginal notes addressed to "Q" referred to his wife. This prompted an account of their relationship and her death ten years previously. ${ }^{59}$

The curators in these circumstances entered indirectly into reminiscence work with veterans. Reminiscence work, an exploration of a person's past (often used to help dementia patients retain a sense of self), is now an established part of many museums' policies.$^{60}$ During the 1970s and 1980s reminiscence work within museums was uncommon, although there was an awareness of the underlying social obligation toward donors incumbent upon a public institution. When veterans decided to donate an object, the impulse to pass on their life story provided a strong impetus to transmit the memories associated with the item as well.

The experiences that donors shared with the museum do not engage in the pathos-laden discourse about the war that was emerging at this time. At times it seems that first-generation donors may even have been reacting to this rhetoric when the letters that accompanied the items being donated 
presented counternarratives that resisted the popularized interpretation of the conflict. ${ }^{61}$ Thus, in a letter to the DLI Museum, a woman who had lost her elder brother during the Battle of the Somme wrote:

A few years ago I saw an advertisement by a lecturer in history at Sunderland Technical College asking for donations of memorabilia of the First World War. However so many of these lecturers are against war for any cause and use any records to denigrate bravery and talk about jingoism that I did not respond. I was a college lecturer myself thus having some knowledge of these activities... His [her brother's] one desire was to go to the front and fight for freedom, like so many of his generation. They were all idealists. But he was clever, and a scientist, he was sent on numerous courses so that he could instruct others. I can also remember still with great sadness when the telegram came one Friday evening to say he was missing believed killed.... So it makes me very sad when suggestions are made for doing away with Remembrance Sunday. ${ }^{62}$

This narrative of pride contains echoes of the interwar period when parents who mourned their dead children believed that they had died for a just cause ${ }^{63}$ Here we find a sibling who rejected a "lions led by donkeys" narrative and who chose to donate to an institution that she felt would properly respect her brother's memory. Even though these memories were stored in a museum that described the conflict as "miserable, static, and frequently bloody," these complex variations of interpretations of the past coexisted within the museum and provided hidden alternatives to the largely homogenous idea of war that was circulating among the general public at the time. ${ }^{64}$ Although these counternarratives were presented by some veterans and their contemporaries, they were not incorporated into the interpretation of the war that the museum presented to the public.

The curators at the DLI Museum seemed to view the donations in different terms. Rumsby, in particular, often wrote letters to the donors that framed their gifts as a form of memorialization. In the standard letter of thanks sent to the donor he would often include an explicit phrase such as "the medals will make a fitting memorial to your husband's services." 65 Upon occasion, Steven Shannon, a curator at the museum during most of the period in question, sent unsolicited material about the war to veterans. For example, in his reply to an ex-soldier who donated a pair of 
field glasses in 1978, Shannon mentioned that he had read the history of the 5th Battalion DLI in which he had found the donor's name and was therefore enclosing "a photocopy of the chapter on the Second Battle of Ypres," adding "[i]t might bring back some memories for you." ${ }^{66}$ Occasionally a curator would meet donors when they came to the museum to donate an item or arrange with them to come and view the item when it was in place, in order to make them feel that their contribution to the museum was valued. ${ }^{67}$

This perception of donation as a form of memorialization was explicitly shared by a small number of the donors. There were, for example, donors who wanted their items to be accessioned into the museum in time for a significant anniversary. One such donor tried to persuade her cousin to donate a complete family archive of her uncle's material "before the anniversary of his [her uncle's] presumed death on the 27th May." 68 Despite her cousin's opposition, the donor split the family archive and sent the material in her possession to the DLI in order to meet the date. Other donors adopted explicit commemorative language in their letters, such as one woman who noted that her donations were "in memory of my late husband's brother." ${ }^{69}$

These perceptions of donation-as-memorialization were not only expressed by those with a connection to the regiment but also by those with no obvious connection to it. After visiting the museum one man continued his day trip to the city and visited the market in Durham city center. At the market he found a Victory Medal belonging to a DLI soldier, bought it and promptly donated it to the museum. ${ }^{70}$ Another donor felt compelled to donate a letter found by her husband because of the emotions elicited when reading it. As she explained: "My husband, a plumber, found it lying in an empty house he was working in. Having read it, he couldn't throw it away-we feel it really is a little piece of history. It is so beautiful and nostalgic I find it impossible to read with dry eyes." ${ }^{\text {"1 }}$ These are unusual examples as there were only five documented cases of donors without any relation to the original owner of the item. Nonetheless all of these donors understood their donations as an act of remembrance. Alison Landsberg's concept of prosthetic memory is useful for explaining their personal reactions to these objects. In the moment of contact "between a person and a historical narrative about the past, at an experiential site such as a movie theatre or museum ... an experience occurs through which the 
person sutures himself or herself into a larger history."72 The discourse surrounding these donations reflects the emergence of a First World War remembrance that was being shaped by a generation who had no direct experience of the war. These donors, who may not have had any family members involved in the conflict, were seemingly not influenced by a strong family memory of war, and instead adhered to the cultural memory of the war with its emphasis on loss and remembrance.

Nonetheless, the DLI Museum itself is rarely referred to in the letters as a memorial site. While the donation of an object could be seen as a memorial act, this did not necessarily confer memorial status onto the building in which it was housed. The museum was usually regarded as a place of physical security for the object, and the donors were often more concerned with the safekeeping of their items by an official body than by the nature of the museum itself.

\section{FAMILIES AND THE FIRST WORLD WAR}

It was often fear of what would happen if the item was not transferred to the museum that fueled family conflicts during the period. As Astrid Erll suggests, "one of the most interesting questions in studying family history is how culturally available narratives ... shape and or $[$ sic $]$ are refracted by family remembrance." 73 Family memory of the First World War, like any generational transmission, tended to rely heavily on anecdotal stories. In part this was a result of the transmission from personal to communicative memory: the generational memory of the person was reduced to anecdotes frequently repeated during his or her lifetime. With reference to family members' lack of intimate knowledge about their ancestors, John Gillis distinguishes between "the family we live with, and the family we live by," the former being the "real life" family experienced as part of everyday life and the latter being the idea of family and ancestry created from the rehearsal of family stories. ${ }^{74}$ This reflects the transmission of memory from one generation to the next, from the personal and communicative memory of the family "lived with" to the disembodied generational memory of the family "lived by."

The letters to the DLI Museum vividly demonstrate the moment of transition between these two phenomena. The embodied memories of 
first-generation living family members and the second-generation anecdotal family memories of the dead of the First World War generation coexist throughout the 1970s and 1980s, with a gradual shift from the former to the latter as the period progressed and those with lived memories passed away. Families were far more likely to possess only a socially mediated memory of the veteran, bolstered by the retelling of anecdotes while they were alive, which meant that they simply had less information to offer the museum. This process of transmitting a communicative memory of the veteran with whom the object was associated to an institutional memory repository meant that the memory of the person was diluted, unlike in the case of first-generation donors, especially veterans themselves, who had a clearer autobiographical memory that was communicated to the curators.

Within the letters relating to second-generation donations, one-third of correspondents were able to describe the original owner's life in some detail. The other two-thirds could only recite anecdotal evidence of varying reliability, some showing clear signs of a set of family tales that had been told time and again (most likely by the soldier the item belonged to or by his close family). One detailed set of family anecdotes was relayed to the museum by a man who donated his father's recipe book, written while he was serving in France during the war. He wrote a set of amusing tales about his father's wartime service and accidental status as cook ("volunteers were asked for, to go on a cooks course, and my father thought it would be a bit of a holiday"), such as when he made a suet dumpling in a hessian sack which when cooked had "Earls Cement plainly printed on it." A particular family favorite seems to have been an incident when the donor's father, standing in Middlesbrough Railway station, was asked by an elderly lady what the two inverted chevrons on his sleeve signified. He replied, pointing to each in turn, "I got this one for going, and this one for coming back. ${ }^{75}$

Some donors demonstrated an awareness of the anecdotal character of the family memories they were offering in their letters. A particularly reflective donor developed a correspondence with the DLI Museum when he donated his great-uncle Tom Harland's baton and tried to discover further information about his war record in the process. The family believed that he had died in a German prisoner-of-war camp while attempting to escape, but the donor acknowledged that this information was "based on hearsay from older relatives." 76 The curator wrote to the donor listing 
some basic information about Harland's service record to help fill in some gaps in the family memory. ${ }^{77}$ The donor replied:

My great uncle Tom was a legend in my family. I was brought up to look on him as a heroic figure, something like Richard Hannay, the John Buchan character. Your research has not revealed as much as I had hoped, but Private Valentine Harland is obviously the same man, though in my family he was always known as Tom, and I would prefer that name to be used if his walking cane is put on exhibition.... I think I have done my best to honour the memory of my great uncle. His walking cane will lie in the DLI Museum on the 70th Anniversary of his death. For my part, Tom Harland will remain the almost Unknown Soldier. ${ }^{78}$

This letter expresses an unusual self-awareness of the complexities of family memory, and the request for his familial name (Tom instead of Valentine) to be used in museum displays is particularly meaningful as a mark of family dominance over his public remembrance. ${ }^{79}$

Control over the family archive and the question of donation was, however, sometimes contested. Family objects did not always follow a direct line of descent, and at the junction where family heirlooms normally follow a natural passage from one generation to the next family conflict could occur. Within the DLI material these conflicts largely fell within two categories, financial and personal, and varied from minor disagreements to cases where legal assistance was sought in order to demonstrate ownership of the item in question.

The financial disputes essentially revolved around the opposition of family members to selling items for a profit. One woman donated a Military Cross medal awarded to her uncle, who had died when she was seven years old, explaining that she was sending it to the museum because "just to sell the cross to some dealer seems a poor end to the memory of a brave man." ${ }^{80}$ Another donor tried to withdraw his stepfather's medals from the Hartlepool branch of the British Legion in order to donate them to the DLI Museum, explaining "my only fear is that the Club might need money and be tempted to sell them." ${ }^{81}$ Those who contacted the museum perceived the commodification of personal items as abhorrent and many strove to safeguard their items from such a fate by placing them in the DLI Museum. 
One example of the complexity of family disputes began in 1976 when a woman donated her father's medals. Two years later the DLI Museum received a letter from her eldest brother stating that "the medals in question were sent to you against my wishes and as the rightful owner due to the death of my parents I would be very grateful if you would return them to my youngest brother [the eldest was working outside of the country], whose address you have in your possession." 82 Nothing more was recorded until 1985, when the argument began anew. The eldest brother contacted the DLI Museum again to renew his request for the medals and explained that upon the death of both of his parents in the early 1970s he, as the eldest son, had inherited all of their possessions. He let his sister "have all the monies and goods-without hesitation" but wanted to retain their father's medals. However, "because at that time my work entailed a lot of travelling I was unable to stop my sister sending my late father's medals to the museum of the DLI." ${ }^{83}$ As the medals had been donated in the eldest brother's name they were returned to him in June $1985 .{ }^{84}$

The sister learnt of the return of the medals to her brother and immediately contacted the museum stating that she was confused about this, as she believed she had authority over the items. She claimed that when she had donated them she had been asked for her eldest brother's name to be placed on the form, a request she had complied with, with the understanding that she was the donor. Because of this confusion and because the elder brother's name appeared on the donation certificate, the medals were returned to him in June. The sister was not happy with this and explained her family history, saying that she had nursed both of her parents but because of disagreements she and her two brothers were not in contact (a third brother whom she had nursed had recently died) and that the remaining brothers had conspired to work together against her. She claimed that it had been her mother's wish that the medals went to the DLI Museum upon her death. ${ }^{85}$

In August 1985 she contacted a solicitor and wrote informing the museum "it would appear because the property I gave into your safe keeping was legally mine ... I would like this property returned back to you ... I do not want [my brother] to dispose of this property and I feel that he could just do that as time goes on." ${ }^{86}$ Curators replied explaining that they had no legal authority to do this and that she should directly 
contact her eldest brother. The next letter received by the museum from the eldest brother read:

since, it seems, my receipt of my late father's medals there has been a tremendous furore, made by my sister through a solicitor, for the return of the medals to the DLI Museum and Arts Centre. I honour the name of my father too much to drag his name through any court action which might ensure [sic] should I not return the medals and other items to the DLI. So please receive said medals and other items herewith to be retained into perpetuity. ${ }^{87}$

The final letter between the family and the museum is from the sister and dated September 1985:

I know now that they will be ever in accordance with me [sic] late mother wishes. I hope you understand I am most grateful that they were returned before the 20th September as both my mother and three years later my brother died on the same date. This has cost me dearly in many ways but I am most grateful for your patience. ${ }^{88}$

The sister's fierce commitment to seeing the objects returned to their rightful home outweighed any sisterly inclination toward her brother's desire to keep the medals within the family archive. Here the social memories of this particular family were folded into the dates of the mother and brother's death and not the death date of the father (to whom the medals originally belonged). This argument is freighted with notions of duty, out of respect for a deceased parent's wishes, but they became part of a wider family dispute.

The museum therefore could be a contested site, not just between public and private, but between notions of correct modes of maintaining family objects. The donation of items to a public body, for some, was highly troubling: the family archive was not only mythologized but disputed. The gendered nature of this dispute, the perception that sons should have control over the family objects because of their traditional status versus a daughter's entitlement because of her caring role, is significant here. Perceptions of the role of both genders rely on traditional assumptions to bolster their claim, while the sister, in this case, ultimately fulfilled the wish of her mother. 
This raises the question of how usual it was for a woman to donate an item. As the traditional custodians of the family archive, were they able to choose when an item left the family or, as in the case discussed here, did male heirs feel that they ultimately retained responsibility (even if purely in legal terms) for their ancestor's possessions? In the aftermath of the First World War women were assigned gendered roles as mourners and keepers of mementos of the dead. ${ }^{89}$ Museum curators played into this rhetoric of women as mourners: a former curator of the museum recalled that the majority of donors were elderly women who wept in his office as they donated their items. ${ }^{90}$ According to these narratives, women should have provided the vast majority of donations over the twenty-year period under consideration. However, in all three generations more men than women donated. Of the first generation who donated, 70 percent of donors were male. The concept of the holder of the family archive as female is undermined by these donation patterns.

The private/public interface of the family archive is also worth considering here. In some instances, while women may have been the carers for the people and objects within the home, publicly the items were seemingly owned and donated by a male figurehead. This did not mean that men could not also be carers; several letters quoted in this article mentioned the active role that men had taken in caring for donated items. Indeed, in the case of the family conflict over medals described above, the brother had assumed the traditional feminine role of keeper of the family archive but the sister was still a commemorative actor because of the emphasis she placed on her mother's final wishes. In some cases personal relations with the owner were the key factor: it was those who felt closer to the deceased who principally cared for the item, but the pre-prescribed gender roles (of women as custodians but men as legal owners) were enacted upon when the private care of the object was replaced by public ownership.

The end of the 1980s marked an important shift in donation patterns when some members of the younger generation sought to reclaim family heirlooms that had already been donated. ${ }^{91}$ The private became public only to return to the family once more. In 1989 a man asked for the return of his grandfather's war medals. He told the museum that "when he died 14 years ago I was asked if I would like his medals, but being only about 14 years old at the time and very upset at his death I said no. ${ }^{92} \mathrm{He}$ explained that now he felt that they should be kept in the 
family archive alongside the First World War veteran's son's medals from the Second World War. In 1995 a woman wrote to the museum asking for the return of some medals donated by her mother some years before and which had originally belonged to her grandfather. She explained, "my mother died in 1988 and my young son is without grandparents, I am researching our family history to try and give him a sense of identity and would be very pleased if the medals and letters could be returned to us." ${ }^{\prime 3}$ This marked the beginning of a wave of people asking for their family items to be returned, which continued after the period focused on here, possibly spurred by the renewal of public interest in the war.

This new pattern in family interaction with the museum marked the transition phase between generational memory and a disembodied cultural memory of the war. The family members asking for the items to be returned had only vague impressions of the original owner (if at all) but nonetheless saw their items as imbued with enough cultural symbolism (of the war, of their family history, and perhaps of the donor) to request their return. A noticeable absence of veterans at national commemorative events and in new cultural outputs meant that remembrance of the war was once again changing in nature. These requests for the return of items suggest that families did not see the museum as a memorial site for their particular relative, but instead considered that the remembering of a person through their objects in a more intimate home setting was integral to the construction of their family narrative. They thus made a conscious decision to overrule the original donor's reasons for gifting the item to the museum and instead prioritized the needs of the present family as more pressing than those of past family members.

VETERANS, FAMILIES AND THE DONATION OF FIRST WORLD WAR OBJECTS

The 1970s and 1980s witnessed a complex shift in the dynamics between those who embodied a living memory of the First World War and their second-generation successors. At the beginning of the 1970s first-generation donors were dwindling in numbers but largely representative of the embodied experience of war; by the end of the period it was their descendants who offered disembodied anecdotes of an ancestor involved in the conflict. Nicholas Saunders, writing about the First World War, noted 
that with the death of veterans, "our views are [now] inevitably shaped by the physical remains themselves, and by the interpretations of those who had no part in their design, production or original purpose." 94 Of course not every veteran wanted, or was able to, take part in this discourse. An unknown proportion of veterans did not pass on any memories, either to the museum or to their families. The deferred trauma of the First World War could result in the inability to discuss their experiences, either because they thought that others could not understand or as a way of protecting their loved ones, or to avoid reliving traumatic experiences. ${ }^{95}$ Some of these veterans' objects may have been found after their deaths and donated to a museum, but the memories associated with them were not.

The DLI Museum stood at the nexus of competing demands; individual, family, regimental and public. As an institution it was viewed as a store of history, infused with varying degrees of nostalgia and respect by members of the public. The local population could see the museum as a regimental store of old militaria, but they could also regard it as a place freighted with enough respect to want to donate their treasured possessions to it. Donors interacted with the museum both as a community space and as a place that was perceived as especially welcoming to veterans and those with a military connection according to the museum's founding ethos of fostering an esprit de corps.

It was against this background that the dynamic exchange of different types of memories took place: personal to communicative; personal to institutional; and communicative to institutional. In bypassing the intergenerational transmission of memory within the family, either through choice or because there was simply nobody to whom the memory could be transferred, the donor created a continuation of the self. This was important at the end of the individual's life, but its timing was also significant as this was the period when culturally homogenized perceptions of the war were emerging. In some cases it is impossible to disentangle whether personal motivations for donating (the pressing of time) or the social ones (the desire to disrupt the cultural homogeneity) were the key motivator for donation.

The donors seem to have perceived the museum in terms of a memory holder, a safeguard against the passing of time, against being remembered incorrectly and against being forgotten. In instances where veterans had nobody to bequeath an item to or feared that an item might be unsafe 
left in the hands of a relative, they used the museum as a place to store their memories in an assumed safe space. At times the memories relayed to the museum were at odds with the increased cultural homogenization that the museum was promoting. However, as a regimental museum with inherently militaristic associations it was still viewed as the best choice available to donors at the time.

Families who donated often did so at the wish of a loved one who had passed away. Others, as in the case of veterans and their contemporaries, viewed the museum as a natural inheritor for their objects to be held in perpetuity. Yet the museum was not inured to family conflict which arose over the control of the ancestral archive and contestation over a donated item that the family as a whole had not agreed to donate. The family donations indicate that at times control over the family archive was tenuous and put to the test by the donation of items, while in some instances representing a gendered understanding of who the guardian of family memory was.

These transmissions of memory, from personal to communicative to institutional, stood at the intersection between communicative and cultural memory. Donors circumnavigated the standard way of transmitting personal memory (from personal to communicative and familial to anecdotal) and instead attempted to harness their experiences to the growing cultural memory of the period they had lived through. These memory transactions between individual and museum took place in the space where the everyday memory of the communicative transforms into the cultural. The death of the veterans and the decision of the next generation to deposit family items in an institutional repository marked a subtle shift from communicative (embodied) memory to institutional (disembodied) memory of the First World War. The process of donation melds personal and social memory with cultural memory, thus complicating the standard personal-to-social trajectory and illuminating both the complexity of these memory junctures and the agency of those involved in the process.

These complex memory transmissions mark a period when the memory of the First World War was solidifying. Despite the closure of the DLI Museum in 2016 the UK still contains hundreds of small regimental museums, all with similar histories (and perhaps, more importantly, archives) to the DLI. Nearly all museums contain administrative paperwork that sheds light on questions surrounding these types of memory transmission. Far 
from representing a smooth transition from one memory state to another, the actions of the DLI donors suggest that they were keenly aware of the limited reach of communicative memory and that interactions with cultural memory holders were seen as a more effective form of cementing personal and communicative forms of memory about the self. The donors decided that the museum was the best place for preserving their objects and they endeavored to ensure that the museum agreed with them.

\section{NOTES}

I am grateful to staff at the DLI Collection, in particular Gillian Kirkbride, for supporting this research. I also wish to thank James McConnel, Jenny Macleod, Ann-Marie Einhaus, James Koranyi, Rowan Thompson, Erhan Tamur, and the anonymous reviewers for their insightful comments.

1. Brian Bond, The Unquiet Western Front: Britain's Role in History and Literature (Cambridge: Cambridge University Press, 2002), 76.

2. Jay Winter and Antoine Prost, The Great War in History: Debates and Controversies, 1914 to the Present (Cambridge: Cambridge University Press, 2006), 19; Derek Paget, "Popularising Popular History: 'Oh What a Lovely War' and the Sixties," Critical Survey 2, no. 2 (1990): 119.

3. Bond, The Unquiet Western Front, 76; Nóra de Buiteléir, "Under the Magnifying Glass: Investigating the First World War in Recent Crime Novels by Ben Elton, and Jan Eik and Horst Bosezky," Modern Language Review 110, no. 2 (2015): 366; Catriona Pennell, "Learning Lessons from War? Inclusions and Exclusions in Teaching First World War History in English Secondary Schools," History o Memory 28, no. 1 (2016): 41-42.

4. Museums \& Galleries Commission, The Museums of the Armed Services (London: Museums \& Galleries Commission], 1990), Appendix A.

5. The DLI Museum kept three sets of records relating to its objects: log books used at the point of formal accession into the collection; paper acquisition records comprising the original paperwork the donor completed (stored alongside correspondence from the donor); and a set of typed accession notes which provide a more detailed summary of the log books. The log book recording numbers 3000 to 3999 has been lost and it is only recently that the museum has begun to collect information about the objects missing from the records, so accordingly these data have been omitted. On the basis of these records I created a database of First World War objects that entered the collection between January 1970 
and December 1989. As the paper accessions suggest that additional items were donated but not fully accessioned within the time period, I also created a further database of fifty objects that entered the museum with their paper accession slip before 1990 but were recorded in the log books at a later date. The DLI Collection has retained copies of these databases.

6. Dominiek Dendooven, "The Journey Back: On the Nature of Donations to the 'In Flanders Field Museum,'” in Nicholas J. Saunders and Paul Cornish, eds., Contested Objects: Material Memories of the Great War (Abingdon, UK: Routledge, 2009), 60-72. Dendooven's article discusses second-generation donations to the In Flanders Field Museum in the 1990s. To my knowledge this is the only other article which discusses the donation of items to museums by "ordinary" individuals.

7. Matthew Richardson, "Medals, Memory and Meaning" in Saunders and Cornish, eds., Contested Objects, 112-13.

8. Dan Todman, The Great War: Myth and Memory (London: Bloomsbury Academic, 2005), 115-20; 144; Winter and Prost, The Great War in History, 21.

9. Jan Assmann, Religion and Cultural Memory: Ten Studies translated by Rodney Livingstone (Stanford: Stanford University Press, 2006), 24.

10. Aleida Assmann, "Transformations between History and Memory," Social Research 75, no. 1 (2008): 56.

11. Elaine Heurmann Gurian, Civilising the Museum (Abingdon, UK: Routledge, 2006), 89. The other two institutions of memory, she argues, are archives and libraries.

12. Aleida Assmann, "Memory, Individual and Collective," in Robert E. Goodin and Charles Tilly, eds., The Oxford Handbook of Contextual Political Analysis (Oxford: Oxford University Press, 2006), 210-24; Assmann, "Transformations between History and Memory," 213-14.

13. Jan Assmann, "Communicative and Cultural Memory," in Astrid Erll and Ansgar Nünning, eds., Cultural Memory Studies (Berlin: De Gruyter 2008), 109-18; Jan Assmann, "Collective Memory and Cultural Identity," trans. John Czaplicka, New German Critique, no. 65 (1995): 125-33.

14. Assmann, "Memory, Individual and Collective," 220.

15. Heumann Gurian, Civilising the Museum, 4; For more on how museums represent a nexus of memory types, see Susan A Crane, "Of Museums and Memory," in Susan A. Crane ed., Museums and Memory (Stanford: Stanford University Press, 2000), 1-13; Jay Winter, "Museums and the Representation of War," in Wolfgang Muchitsch ed., Does War Belong in Museums? The Representation of Violence in Exhibitions (Bielefeld: Transcript Verlag, 2013), 21-37; Gaynor Kavanagh, "Remembering Ourselves in the Work of Museums: Trauma and the 
Place of the Personal in the Public," in Richard Sandell ed., Museums, Society, Inequality (London: Routledge, 2002), 110-22.

16. Gaynor Kavanagh, Dream Spaces: Memory and the Museum (London: Bloomsbury, 2000), 3-4. Based upon the work of Jay Winter and Emmanuel Sivan, War and Remembrance in the Twentieth Century (Cambridge: Cambridge University Press, 2000), I use the term "remembrance" to mean a mediated recollection of events that is deliberately elicited by those with little or no direct experience of the events in question.

17. Sue Malvern, "War, Memory and Museums: Art and Artefact in the Imperial War Museum,” History Workshop Journal, no. 49 (Spring 2000): 178; also see Andrew Whitmarsh, “We Will Remember Them': Memory and Commemoration in War Museums," Journal of Conservation and Museum Studies 7 (2001): 1-15.

18. Simon Jones, "Making Histories of Wars," in Gaynor Kavanagh ed., Making Histories in Museums (London: Bloomsbury, 1996), 152.

19. Barton C. Hacker and Margaret Vining, "Toward a History of Military Museums," in Robert Douglas Smith, ed., ICOMAM 50: Papers on Arms and Military History 1957-2007 (Leeds: Basiliscoe Press, 2007), 40.

20. By 1987 there were 1,750 museums in the UK, with half of these established after 1971. See John Urry, The Tourist Gaze (London: SAGE, 1990), 94.

21. Barton C. Hacker and Margaret Vining, "Military Museums and Social History," in Muchitsch, ed., Does War Belong in Museums?, 42; Barton C. Hacker and Margaret Vining, "Toward a History of Military Museums," 40; also see Simon Jones, "Making Histories of Wars," 160.

22. Ross J. Wilson, Cultural Heritage of the Great War in Britain (Farnham: Ashgate, 2013), 13.

23. For the IWM recording of oral histories, see Conrad Word, "Ten Years of the Department of Sound Recordings of the Imperial War Museum," Oral History 11, no. 1 (1983): 9-12; Deborah Thom, "Making Spectaculars: Gender in Wartime," in Gail Braybon, ed., Evidence, History and the Great War: Historians and the Impact of 1914-18 (New York: Berghahn, 2008), 48-66.

24. Steven Shannon, "The Durham Faithfuls” 1758-1968: 9th September-8th October 1978 (Durham: Durham Light Infantry and Arts Centre, 1978)

25. Interview with Dr. Steven Shannon, July 27, 2015.

26. Matthew Richardson, "A Changing Meaning for Armistice Day," in Hugh Cecil and Peter H. Liddle eds., At the Eleventh Hour: Reflections, Hopes and Anxieties at the Closing of the Great War, 1918 (Barnsley: Pen \& Sword Books, 1998), 359.

27. Figures from Bond, The Unquiet Western Front, 90.

28. Alan Clark, The Donkeys (London, 1993), 9; David Taylor, "Blood, Mud and Futility? Patrick MacGill and the Experience of the Great War," European 
Review of History 13, no. 2 (June 2006): 229-30. The expression "lions led by donkeys" is attributed to the German Chief of Staff Hoffmann who, upon hearing General Ludendorff exclaim "The English soldiers fight like lions" replied "True. But don't we know that they are lions led by donkeys." Cited in Clark, The Donkeys, 1. In general, the term was taken to mean that the British soldiers were led by incompetent generals who needlessly wasted soldiers' lives.

29. Helen Sandford, The Durham Light Infantry Museum: A Brief History and Guide to the Collections (Durham: Durham Light Infantry and Arts Centre, 1970), 15.

30. Richardson, "Medals, Memory and Meaning," 113.

31. John Rumsby, The Durham Light Infantry Museum (Derby: English Life Publications, 1975), n.p. [7]; also see, G. P. Ward, Faithful: The Story of the Durham Light Infantry (Liverpool: Thomas Nelson \& Sons, [1963?]), 319.

32. Letter from Mr. Rumsby, DLI, November 11, 1975, no Acc. No., DLI Collection (DLIC), Donor Files.

33. Letter to DLI, August 11, 1975, Acc. No. 2015, DLIC, Donor Files.

34. Margaret Higgonet, "Souvenirs of Death," Journal of War and Culture Studies 1, no. 1 (2008): 72-74.

35. These figures relate to the 648 objects fully accessioned into the museum during the period. The percentages from the second, smaller, database are: paper, 62 percent; memorials, 10 percent; medals, 10 percent; miscellaneous, 8 percent; collections of items, 6 percent; uniforms, 4 percent. The number of medals fully accessioned may have been artificially increased due to the desire to accession as many medals as possible before the opening of the DLI Museum's refurbished medal room in 1988 .

36. Donors who wanted to donate weaponry were advised to contact the Imperial War Museum; letter from DLI, March 14, 1978, DLIC, Donor Files.

37. Letter to DLI, February 6, 1984, Acc. No. 4069, DLIC, Donor Files.

38. They were eventually donated to the DLI Museum. Letter to DLI from Derby Museum and Art Gallery, April 14, 1983, Acc No. 2860, DLIC, Donor Files.

39. Letter to DLI, October 20, 1981, Acc. No. 2720, DLIC, Donor Files.

40. See, for example, letters to DLI, April 1971; December 20, 1972; May 7, 1976; June 16, 1976, Acc. No. 1255, DLIC, Donor Files.

41. Letter to DLI, August 14, 1971, Acc No. 1753, DLIC, Donor Files.

42. Letter to DLI, October 5, 1983, Acc. No. 2885; letter to DLI, February 9, 1973, Acc. No. unknown, DLIC, Donor Files. This seems to have been true for other regiments as well. Geoffrey Moorhouse, in Hell's Foundations: A Town, Its Myths and Gallipoli (London: Faber and Faber, 1992), 220, gave an example of the sister of a Victoria Cross winner who offered (for a small fee) the soldier's 
VC to his old regiment, the Lancashire Fusiliers, in 1964. They told her that they would be delighted but she would get a lot more money in London. She declined their suggestion, saying that she only wanted the regiment to have it.

43. Dendooven, “The Journey Back," 67.

44. Of other first-generation donors, wives of veterans donated 45 percent of items; sisters 15 percent; brothers 6 percent; and other relatives (siblings-in-law, half-siblings and cousins) 6 percent. Among the second-generation donors, sons donated 44 percent of items, daughters 40 percent, sons-in-law 6 percent and nieces 7 percent (the gender of the remaining 3 percent of donors is unknown).

45. Letter to DLI, July 17, 1971, Acc No. 1668, DLIC, Donor Files.

46. Letter to DLI, December 13, 1965, Acc. No. 1711, DLIC, Donor Files. 47. Letter to DLI, March 3, 1974, Acc. No. 2126, DLIC, Donor Files.

48. Letter to Major Lofthouse, October 18, 1973, Acc. No. 2176, DLIC, Donor Files; letter to DLI, August 27, 1978, Acc. No. 2176, DLIC, Donor Files.

49. Letter to DLI, November 3, 1970, Acc. No. 1203, DLIC, Donor Files.

50. Letter to DLI, December 28, 1982, Acc No. 2690, DLIC, Donor Files.

51. Peter Coleman, "Reminiscence within the Study of Ageing: The Social Significance of Story," in Joanna Bornat, ed., Reminiscence Reviewed: Perspectives, Evaluations, Achievements (Buckingham: Open University Press, 1994), 8-9; Gillian Cohen, "The Effects of Ageing on Autobiographical Memory," in Charles P. Thompson et al., eds., Autobiographical Memory: Theoretical and Applied Perspectives (Mahwah, NJ: Lawrence Erlbaum Associates, 1998), 105-7. See also Hans Markowitsch and Harald Welzer, The Development of Autobiographical Memory (Hove: Psychology Press 2010).

52. It is possible that some veterans split their collections between the DLI Museum and their family.

53. Letter to DLI [1975], Acc No. 2271, DLIC, Donor Files.

54. Margaret Gibson, Objects of the Dead: Mourning and Memory in Everyday Life (Melbourne: Melbourne University Press, 2008), 41.

55. Letter to DLI, March 1983, Acc. No. 2788, DLIC, Donor Files.

56. Letter to DLI, December 16, 1981, Acc. No. 2690, DLIC, Donor Files.

57. Letter to DLI, November 10, 1970, Acc. No. 1246, DLIC, Donor Files.

58. Letter to DLI, August 21, 1974, Acc. No. 2176, DLIC, Donor Files.

59. Letter to DLI, November 28, 1975, Acc. No. 2092, DLIC, Donor Files.

60. Helen Chatterjee, Sonjel Vreeland and Guy Noble, "Museopathy: Exploring the Healing Potential of Handling Museum Objects," Museum and Society 7, no. 3 (Nov. 2009): 175.

61. See Justin Court, "Picturing History, Remembering Soldiers: First World War Photography between the Public and the Private," History \& Memory 29, no. 1 (2017): 72-103, for a discussion of how these personal items that provided 
a counterpoint to the homogenous cultural memory of the war can be utilized in the present.

62. Letter to DLI, January 23, 1987, Acc. No. unknown, DLIC, Donor Files.

63. Jay Winter, Sites of Memory, Sites of Mourning: The Great War in European Cultural History (Cambridge: Cambridge University Press, 2014), 78-85.

64. Sandford, The Durham Light Infantry Museum, 15.

65. Letter to donor, October 12, 1973, Acc. No. 2090, DLIC, Donor Files.

66. Letter to donor, November 3, 1978, Acc. No. 2500, DLIC, Donor Files.

67. Letter November 1, 1977, Acc. No. 2443, DLIC, Donor Files.

68. Letter to DLI, May 11, 1987, Acc. No. 4634, DLIC, Donor Files.

69. Letter to DLI, April 7, 1982, Acc. No. 2694, DLIC, Donor Files.

70. Letter to DLI, September 13, 1987, Acc. No. 4215, DLIC, Donor Files.

71. Letter to DLI, August 22, 1980, Acc. No. 2564, DLIC, Donor Files.

72. Alison Landsberg, Prosthetic Memory: The Transformation of American Remembrance in the Age of Mass Culture (New York: Columbia University Press, 2004), 2 .

73. Astrid Erll, "Locating the Family in Cultural Memory Studies," Journal of Comparative Family Studies 42, no. 3 (2011): 312.

74. John Gillis, A World of Their Own Making (Oxford, 1996), xv-xix.

75. Letter to DLI, April 1, 1984, Acc. No. 4078, DLIC, Donor Files.

76. Letter to DLI, July 3, 1988, Acc. No. unknown, DLIC, Donor Files.

77. Letter from DLI, October 6, 1988, Acc. No. unknown, DLIC, Donor Files.

78. Letter to DLI, October 22, 1988, Acc. No. unknown, DLIC, Donor Files.

79. His CWGC headstone in Hamburg Cemetery simply reads Pte T.V.F. Harland.

80. Letter to DLI, May 1987, Acc. No. 4090, DLIC, Donor Files.

81. Letter to DLI, July 29, 1979, Acc. No. unknown, DLIC, Donor Files.

82. Letter to DLI, July 28, 1978, Acc. No. 2531, DLIC, Returned Donations File.

83. Letter to DLI, June 17, 1985, Acc. No. 2531, DLIC, Returned Donations File.

84. Letter from DLI, August 13, 1985, Acc. No. 2531, DLIC, Returned Donations File.

85. Letter to DLI, August? 1985, Acc. No. 2531, DLIC, Returned Donations File.

86. Letter to DLI, August 8, 1985, Acc. No. 2531, DLIC, Returned Donations File.

87. Letter to DLI, September 11, 1985, Acc. No. 2531, DLIC, Returned Donations File. 
88. Letter to DLI, September 1985, Acc. No. 2531, DLIC, Returned Donations File.

89. Joy Damousi, "Mourning Practices," in Jay Winter ed., The Cambridge History of the First World War, vol. 3, Civil Society (Cambridge: Cambridge University Press, 2014), 360.

90. Interview with Dr. Steven Shannon, July 27, 2015.

91. The return of objects was tightly controlled by the Board of Trustees.

92. Letter to DLI, June 29, 1989, Acc. No. 2645, DLIC, Returned Donations File.

93. Letter to DLI, May 31, 1995, Acc. No. 2857, DLIC, Returned Donations File.

94. Nicholas Saunders, "Material Culture and Conflict: The Great War, 19142003," in Saunders ed., Matters of Conflict: Material Culture, Memory and the First World War (Abingdon, UK: Routledge. 2004), 5.

95. Jay Winter, War beyond Words: Languages of Remembrance from the Great War to the Present (Cambridge: Cambridge University Press, 2017), 172-73; Marlene A. Briggs, "Dis/composing the First World War in Britain: Trauma and Commemoration in the Testimony of Harry Patch, 1998-2008," History \& Memory 28, no. 1 (2016): 92. For a precis of recent work on silence as an active process which complicates the assumed binary of remembering/forgetting, see Alexandre Dessingué and Jay Winter, "Remembering, Forgetting and Silence," in Dessingué and Winter, eds., Beyond Memory: Silence and the Aesthetics of Remembrance (Abingdon, UK: Routledge, 2016), 1-12.

AnN-Marie Foster is currently completing her AHRC funded PhD dissertation, titled "The Ephemera of Remembrance in the Wake of War and Disaster, c. 1899-1939," at Northumbria University, UK. She is interested in the ways families were impacted by the sudden death of a loved one through war and disaster in the twentieth century. (ann-marie. foster@northumbria.ac.uk) 